\title{
IMPLEMETATION OF MODEL SAVI (SOMATIC, AUDIOTORY, VISUALIZATION, INTELLECTUAL) TO INCREASE CRITICAL THINKING ABILITY IN CLASS IV OF SOCIAL SCIENCE LEARNING ON SOCIAL ISSUES IN THE LOCAL ENVIRONMENT
}

\author{
Dr. Dadang Iskandar, M.Pd ${ }^{1)}$, Acep Roni Hamdani, M.Pd ${ }^{2)}$, Teti Suhartini, S.Pd. ${ }^{3)}$ \\ 1) PGSD FKIP Pasundan University, Jl. Wartawan IV No. 22 Bandung \\ dang_isk@yahoo.com \\ 2) PGSD FKIP Pasundan University, Jl. Wartawan IV No. 22 Bandung \\ acepronihamdani@unpas.ac.id \\ 3) SDN Tanjung III \\ tetisuhartini@gmail.com
}

\begin{abstract}
This research is motivated by the lack of critical thinking skills of fourth grade students of SDN Tanjung III, Subang district. On the basis of the need for repairs done either by applying the model of SAVI (Somatic, Auditory, Visualization, Intellectual). So the purpose of this study was to determine the increase critical thinking skills of students in Social Science before and after applying the model SAVI, the performance of teachers in applying the model SAVI, activities and students' response to the model SAVI. The method used in this research is the CAR (Classroom Action Research). Subject of research that fourth grade students of SDN Tanjung III by the number of students as many as 23 people. The instrument used was $L K S$ (Student Worksheet), observation sheet of students and teachers as well as student questionnaire responses. From these results, it can be concluded that by applying the model in study SAVI social science with social problems in the local environment can enhance students' critical thinking skills. The result can be seen from the percentage of the overall level of mastery learning increased from $52.2 \%$ in the first cycle, $78.3 \%$ in the second cycle and $100 \%$ in the third cycle. The average grade class of students increased from 44.3 prasiklus of data with less criteria, up to the third cycle, which reached 91.3 with the criteria very well. With the improvement of students' critical thinking skills that are calculated based on the n-gain of 0.53 with the criteria of being in the first cycle, and 0.65 with the criteria of being on the second cycle, and 0.81 with the high criteria of the third cycle. The results of observations also showed that the ability of teachers and students' activity in applying the model of SAVI increased. Based on questionnaire responses, $100 \%$ of students showed interest in learning social science model with SAVI. Therefore, it is suggested that teachers use models SAVI to enhance the critical thinking skills of students so that students used to learn to analyze problems well.
\end{abstract}

Keywords: Model SAVI (Somatic, Auditory, Visualization, Intellectual), critical thinking skills students, the Learning Social Science

\section{INTRODUCTION}

Education is a conscious effort made by humans in order to grow flowers well in the surrounding environment, in school, community and family. Primary School is one form of educational units that conduct educational programs for six years. The aim of education in primary schools is provided supplies basic ability for students to develop the skills they have. In the implementation of education in primary schools cling to the curriculum. The curriculum is a set of plans and arrangements regarding the objectives, content and learning materials as well as methods used to guide the delivery of learning activities to achieve specific educational objectives. In order to develop human resources (HR) quality through education, the government through the curriculum SBC recommend Social Science as one of the compulsory subjects are given to elementary school students to high school.
According to [1] Social Science is a discipline that studies the intellectual humans as social beings scientifically, focusing on humans as members of society and on a group or society which he forms. This is in line with the opinion of Hamalik [2] that the purpose of Social Science, namely: 1) Preparing students for further studies in the field of social science, subjects such as history, geography, economics, and cultural anthropology should be given partial , Social studies, who had not fragmented efforts need peramuan parts of other subjects; 2) Social Science essentially a compromise between 1 and 2 above science. As a simplification and screening of social sciences, with the ability and intelligence of the students; 3) Learn closed areas or social issues that deserve to be discussed in public. The material relating to the area of economic, social knowledge to the political, and even cultural fields; 4) Educate students to become active citizens. In the context of culture through scientific and psychological treatment appropriate; 5) According to the 
guidelines specific areas of study Social Science, learning activities Social Science lead to two things: a) the values and attitudes contained by Pancasila and the 1945 Constitution as a fundamental and intensively imparted to the students so that nurtured the will and determination to live responsibly for the advancement of self, nation, state, and country, b) teach the basic concepts of sociology, geography, economics, history, civics, pedagogical and psychological; 6) Develop the ability to think critically and creatively, inquiry, problem solving, and social skills, and build commitment and awareness of social values and humanity; 7) Improving the ability to cooperate and compete in a pluralistic society, both nationally and globally.

In line with these objectives, educational objectives Social Science is "nurture students to become good citizens, who have the knowledge, skills and social awareness useful for him as well as for society and the state" [3]. While the details [4] to formulate educational purposes Social Science is oriented to student behavior, namely: 1) knowledge and understanding; 2) attitude to life learning; 3) social values and attitudes; 4) skills. From the above it can be concluded that Social Science is an attempt to obtain, understand the knowledge about the environment and the various activities that are nearby as well as other social phenomena, so that he can solve social problems that occur in their environment.

Learning social studies for elementary school children should be adapted to the stage of cognitive development. At the age of elementary school students is an important phase in the life of a person, according to the theory of cognitive development [5] children at age 7 to 11 years are at the concrete operational stage. Where in this phase children have been able to know the symbols but can not understand the things that are abstract. Thus, learning needs to be designed that allow the students can see, feel and do something concrete. The role of teachers as educators should be able to design a learning process that makes the material is abstract can be mastered easily by the Social Science students so that learning objectives can be met.

From the description above can be concluded that teachers as educators must design a learning process so as to make all students reach the learning objectives of Social Science, the Social Science can be expressed so that the learning goes well. In social studies in primary school course examines various social problems that occur in the environment. Material submitted must be understood in depth, thus requiring a learning process that emphasizes direct observation through the use and development of skills Social Science. Do not let the students think that learning materials Social Science just need to remember and memorize so it does not require the ability to think critically, when the destination Social Science above has described one of his goals is to develop the ability to think critically and creatively, inquiry, problem solving, and social skills, and build commitment and awareness of social values and humanity.

[6] suggests that in the twenty-first century there are four minimum learning competencies that must be mastered, one of them is the ability to think critically. According to [7] critical thinking is an activity with a critical mind to suit a wide variety of intellectual standards such as clarity, relevance, adequacy, coherence and others. For that students are required to have the ability to think critically is good that the students were able menungkapkan their opinion regarding the material of the lessons learned by them and can understand and analyze the problems on the lessons and find a solution to solve the problem, especially in social studies learning and that students are able and ready to compete globally in the future.

According to [8] studied the relative principles generally accepted one of them is the direct involvement or experience. Learning must be done by the students, thus students must experience, learning can not be delegated to others. It was reinforced by Dale [9] that the classification of a learning experience that is poured dalahm cone experience suggests that good learning is learning through direct experience. Thus the concept of the student obtained through this process will be more meaningful and lasting for students directly involved in the thought process. But in reality, not a few teachers still use conventional learning in the learning process, while conventional learning less support critical thinking skills of students for learning centered on the teacher (Teacher Center) and teachers tend to use the lecture method in presenting the material so it is only suitable for students who have style audiotori learning that can easily comprehend the material simply by listening to the explanation from the teacher. Unlike the students who have learning styles somatic, visual, and intellectual they would be difficult in the face of teaching learning methods lectures, in addition students will feel tired and bored when learning takes place passively, this also affect the low ability of critical thinking in class IV SDN Tanjung III, based on the results of the analysis of preliminary data from 23 students only 3 students with a percentage of $13 \%$ stated achieve Criteria for completeness Minimal (CCM). And as many as 20 students with a percentage of $87 \%$ has not been reached Criteria for completeness Minimal (CCM). With an average of 44.3 with the results of the evaluation study less category.

It is important for a teacher to have a strategy in order to anticipate this problem, create a fun learning environment, engage students actively, and facilitate student learning.From several alternatives that can be used, researchers prefer to apply the model SAVI (Somatic, Audiotory, Visualization, Intellectual).

Model SAVI was first introduced by Dave Meier, he said that learning SAVI embrace flow cognitive science modern states to learn the most good is emotional, the whole body, senses, and all the depth and breadth of personal, respecting individual learning styles other realize that people learn in different ways [10]. Additionally [11] suggests that learning involves more senses to enhance understanding of learners optimally. For the model of SAVI is most appropriate in social studies material social problems in the local environment, because it combines four student learning. With so students can attend learning activities well, through a series of learning activities involving gestures, sense of hearing, sense vision and 
thinking of students in a learning process. Students can practice learning materials and direct experience so that students are easier to remember and understand the essence of the material being taught to be able to train their critical thinking skills.

Social studies is not only enough to lecture only, therefore there should be a practice or real process easier for students to be able to find the concept of a learning material, so students can understand the concept of what is taught to develop their critical thinking skills. Based on the above, through the application of models SAVI is expected to assist students in improving critical thinking skills in social studies.

\section{BASIC THEORY}

\section{Model SAVI}

\section{a. Definition Model SAVI}

Model SAVI is a form of learning created by Dave Meier in his book entitled The Accelerated Learning Handbook, the underlying theory Meier, in proposing the SAVI approach is the theory of active learning that is termed [12] with the Learning Based Activities (LBA). This theory is backed by [12] education in New England in the 19th century who tend to view the body of the human mind that it is separate and distinct. Thus, the rational mind the focus of education, while the body is considered not relevant to the learning process, not only the physical movement is not considered important, but also disturbing. In addition, many cases that mention learning to use physical movement is a sign of low intelligence or innate learning disabilities, the activity of the body and mind are separated in learning activities so that learning takes place stiff and unpleasant. In addition, education in New England at the time of the emphasis on individual learning. This was opposed by Meier and encouraged him to do research.

Meier [12] reveals also that learning is not a separate cognitive event but something that involves the whole person (body, mind and soul) and the intelligence intact.Opinion was delivered Meier in a research conclusion that man has a dimension of somatic, auditory, visual and intellectual. Based on this view Meier propose an active learning approach called SAVI approach. SAVI approach is pressed learning by utilizing the senses of students.

[13] explains that the model of SAVI is a learning model that combines four student learning that is somatic, auditory, visual, and intellectual. Where in this learning model learning students can move, speak or hear, see and think directly what they are learning, so that learning becomes more meaningful.

According to [14] theory that supports learning SAVI is Accelerated Learning, learning based on constructivism, theory of multiple intelligences. SAVI Learning menganutaliran modern cognitive science that learning is best to involve the emotions, the whole body, all the senses, and all the depth and breadth of personal, respect the other individual learning styles by realizing that people learn in different ways.

\section{b. Basic Principles of Learning SAVI}

Due SAVI learning in line with the movement of Accelerated Learning (AL), the principle is also in line with the AL Meier [12] principles, namely:

1) Learning involves the whole mind and body

2) Learning means to be creative instead of consuming.

3) Cooperation helps the learning process

4) Learning takes place in benyak levels simultaneously

5) Learning comes from doing the work itself with feedback.

6) Positive emotions are very helpful learning.

7) Brain-imagery absorb information instantly and automatically.

So basically this SAVI learning further highlight how students create their own creativity. This will affect the students' way of thinking becomes more open and try to dig ability in acquiring new knowledge.

c. SAVI Learning Characteristics

Meier [12] describe the characteristics of the four sections, namely:

1) Somatic

Somatic comes from the Greek meaning of the body soma. So, Somatic learning means learning with tactile, kinesthetic, involves physical as well as using and moving your body while learning. Activity-based learning in general is much more effective than those based presentations and materials. Physical movement increases mental processes, parts of the human brain that are involved in body movement (motor cortex) is located right next to the part of the brain used for thinking and problem solving. Therefore, blocking the movement of the body means that hinder the mind to function optimally. Instead, it involves the body in learning tends to generate fully human integrated intelligence.

2) Auditory

Learning to speak and hear. Our minds are more powerful than we realize, our ears continuously capture and store information even without us knowing. When we create own voice by speaking a few important areas in our brain becomes active. This can be interpreted in learning teachers should encourage students to talk about what they are learning, translating the experience of students with sound. Talk to them when solving problems, making the model, gather information, create a work plan, master the skills, making reviews the experience of learning, or creating personal maknan meanings for themselves.

3) Visual

Learn by observing and describing. In our brain there are more devices for processing visual information than all the other senses. Any student who uses visual learning easier if it can see what is being talked about a speaker or a book or a computer program. In particular, a good visual learners, ie when they can see examples from the real world, diagram, map ideas, icons and so when learning.

4) Intellectual

Learning by solving problems and thoughtful. Measures learners do something with their minds internally when using intelligence to reflect on an experience and create 
relationshSocial Science, meaning, purpose, and value of the experience. This is reinforced by the intellectual meaning is part self reflect, create, and solve problems.

2. Critical Thinking Skills

a. Understanding Critical Thinking

Critical thinking is the ability to think one should have, among students in elementary school. This ability must be trained since elementary school so that students do not feel trouble when you find problems or tasks that require the use of the capacity to think, especially critical thinking skills of students in analyzing and solving problems in the learning process.

As expressed by [15] thinks is a mental activity in order to formulate understanding, synthesize, and draw conclusions. [16] argues that thinking is an activity of the human person which lead to the invention directed to a destination. Human thinking to find knowledge and understanding he pleases. Santrock [17] also expressed his opinion that thinking is to manipulate or manage and transform the information in memory. Thinking is often performed to form concepts, reasoning and wonder critically, make decisions, think creatively and solve problems.

If you think a part of the brain that is always done to organize information in order to achieve a goal, then the critical thinking is part of the thinking brain is also performed. [17] revealed that the ability to think involves six types of thinking, namely, metacognition, critical thinking, creative thinking, cognitive processes, the ability to think and understand the role of core content knowledge. According Santrock [18], critical thinking is reflective thinking and productive, as well as involving the evaluation of evidence. While [19] argues that critical thinking means mental processes are effective and reliable, are used in pursuit of relevant knowledge and true about the world.

Another definition put forward by Glaser [7] defines critical thinking as 1) an attitude would think deeply about issues and things that are within the reach of one's experience; 2) knowledge-knowledge of inspection methods and logical reasoning; and 3) a kind of a skill to apply these methods. Critical thinking requires effort to examine any belief or knowledge assumptive based on supporting evidence, and conclusions resulting advanced.

Based on several expert opinions above, researchers can conclude that critical thinking is a process of mental activity that is focused and clear to be able to find and solve the problem in a systematic, critical and creative with good reason in terms of indicators think critical that ultimately produce a concept believed to be based on reliable sources.Critical thinking skills is an ability that needs to be trained and developed student, given the ability to think critically affect students' way of thinking when it finds problems or tasks that require students to think critically and to help students understand concepts in depth Social Science. In addition, conditions are rapidly growing world requires people to have critical thinking skills to address the global challenges that exist, to encourage students to come up with ideas or new thinking about the world. Students can tell which opinions are relevant and irrelevant, making conclusions by considering the data and facts.

b. The purpose of Critical Thinking

Johnson [16] says that the purpose of critical thinking is to achieve a deep understanding. Meanwhile [6] suggests that the purpose of critical thinking is simple: to ensure that our thinking is valid and correct.

Based on the above opinion, it can be said that the purpose of critical thinking is to achieve a deep understanding of a material or concept so as to ensure that the students' thoughts on the material or the concept is valid and correct along the right reasons.

c. Indicators Critical Thinking Skills

The indicators that will be used in research to measure critical thinking skills are divided into 5 groups according to [20], namely: 1) provide an explanation (elementary clarification); 2) providing basic skills (basic support); 3) find a conclusion(inference); 4) make a further explanation (advanced clarification); and 5) set the strategy and tactics (strategies and tactics).

\section{METHODS}

\section{Research sites}

The location of this research is in SDN Tanjung III located at Jalan Cipunagara Km. 8 Village Parigimulya Cipunagara District of Subang Regency 41257.

\section{Research subject}

The subjects were students of class IV SDN Tanjung III, amounting to 23 students. This research subject is very heterogeneous views of his ability, that there are students with high ability, medium, low and very low.

\section{Design Research}

The study design will be used referring to the model developed by Mc. Taggart [21] is the spiral model. This model has four stages, namely stages: 1) planning ;2) action ; 3) observation ; 4) reflection

\section{DISCUSSION}

\section{Critical Thinking Skills Students After Applying Model SAVI}

Through the results of the first cycle, second cycle and third cycle show that by applying the model SAVI can enhance students' critical thinking skills in social studies class IV SDN Tanjung III material social issues on the local environment. It can be seen from the increase in the average score of students after the given action and improvements in each cycle, the average value of the critical thinking skills of students before being given the mere act of 44.3 to less category and the results of the first cycle studies show that the ability to think critically students has increased by an average of 72.5 in both categories. Then increased to 83.2 in both categories once in the second cycle and the third cycle increased back to 91.3 at an average yield of the third cycle are included in the category of Very Good. The percentage of students in the classical mastery learning has increased.Before the given action, as many as three students with a percentage of $13 \%$ stated achieve Criteria for 
completeness Minimal (CCM), while 20 students with a percentage of $87 \%$ has not been reached Criteria for completeness Minimal (CCM), and after being given the action in the first cycle of students who otherwise completed the first cycle were 12 students with a percentage of $52.20 \%$ otherwise reach Criteria for completeness Minimal (CCM). In cycle II increased to 18 students with a percentage of $78.30 \%$ are reached Criteria for completeness Minimal (CCM). While in the third cycle as of 23 students with $100 \%$ persetase otherwise reached Criteria for completeness Minimal (CCM). This is supported by a statement that $100 \%$ of students stated that learning Social Science model with SAVI make students happy and interested in social studies, and as much as $100 \%$ of students find a simple way to understand the subject matter Social Science model with SAVI. This is supported by the opinion [22] states that the best learning is learning by experiencing something that is by using the five senses. Besides Cornbach, Glaser [23] suggests that learning involves more senses to enhance understanding of learners optimally. Learning with media images, video, real media, songs and compose the word does not make the students understand the material it is stated by the positive response of students by $100 \%$. Supported also by the theory [24] which states that the learning system which involves the use of various props such as learning objects, interactive tools, video clSocial Science, drama, music, smells, and other creative elements capable of providing a stimulus to make the students' responses woke case this triggers the attention and comprehension of students. A total of $100 \%$ claim that the students enjoy learning Social Science model with SAVI of the learning model that is usually because it can use the senses and limbs in learning. [12] states that if the student is in a state that is relaxed, open, less depressed, and have positive feelings learning will take place properly, whereas if the student is in a state that otherwise learning will be slow and not even helpful at all.

2. Response Against Student Learning Application Model SAVI at Social Science

At the beginning of fourth grade students who become subjects in this study had a positive attitude toward social studies, but not optimal, it is proved by the results of the calculation of the questionnaire that $56.50 \%$ of students showed interest in social studies learning, but learning is given in a way that is saturating. This is also supported by the results of questionnaires that $65.2 \%$ of students stated learning very unpleasant Social Science before using SAVI models. Additionally only $52.20 \%$ of students agreed that the Social Science is very useful for everyday life. However, after the researchers applied a model SAVI interest of the students towards learning Social Science increased to $100 \%$, and they stated that the SAVI models makes them happy to lessons learned by the Social Science as a model SAVI interesting and not boring. This is supported by the opinion [25] stated that by using the senses as a means of sensory information, students will be able to build a real picture in mind so that the sensory experience into knowledge that is not forgotten. [24] which states that the learning system which involves the use of various props such as learning objects, interactive tools, video clSocial Science, drama, music, smells, and other creative elements capable of providing a stimulus to make the students' responses awoke this triggers the attention and the terms of students 'understanding and use of instructional media after the researchers adjusted the model SAVI make a positive response to the students' learning SAVI at $100 \%$, that the media can help students understand the material. [12] revealed that the body and mind is a unity that can not be dipidahkan, therefore learning by engaging the senses and physical activity can affect both and help the learning process, from the theory $100 \%$ revealed that students were delighted to learn Social Science SAVI models because it can use the senses and limbs. [26] states that the best learning is learning by experiencing something that is by using the senses, it is supported by student responses at $74.0 \%$ stating that the model of SAVI students become more daring in expressing his opinion and $91.3 \%$ of students are more motivated to learn Social Science after getting this learning. From the results of student questionnaire responses can be concluded that the students' response to social studies learning by using model SAVI declared positive.

\section{Conclusion}

1. Critical thinking skills of students after applying the model SAVI increases. It is based on the analysis of data from the average score of students 'critical thinking skills before being given action only 3 (13.0\%), which reached Criteria for completeness Minimal (CCM), an average of 44.3 students' learning outcomes with less category, the first cycle increased to $12(52.2 \%)$, which reached Criteria for completeness Minimal (CCM), averaging 72.5 with the learning outcomes of both categories, and the second cycle increased to $18(78.3 \%)$ students who otherwise reach Criteria for completeness Minimal (CCM) with an average of 83.2 learning outcomes with both categories once and optimal improvement occurred in the third cycle as of $23(100 \%)$ or all students otherwise reach Criteria for completeness Minimal (CCM) with an average of 91.3 to learning outcomes either category yet. The increase in critical thinking skills of students in the third cycle 0.89 to a high category.

2. Student responses to the application of learning models in social studies learning materials SAVI social problems in the local environment tend to be more positive. It can be seen from the analysis of student questionnaire responses. Initially only $56.5 \%$ of students who showed interest in learning. But after applying the model SAVI student response increased to $100 \%$ which states that students feel happy and interested in learning Social Science. And $100 \%$ easier for students to understand the material because students can take advantage of the sense organs and limbs during the learning process.

\section{REFERENCE}

[1] Sayer, a. (2000). Realism and Social Science. Radical philosophy reader (Vol. 1). https://doi.org/10.4135/ 9781446218730

[2] Amri, S. \& Ahmadi, IK. (2010). Proses Pembelajaran Kreatif dan Inovatif dalam Kelas. Jakarta: PT. Prestasi Pustakarya. 
[3] Anttonen, A., \& Sipila, J. (1996). European Social Care Services: Is It Possible To Identify Models? Journal of European Social Policy, 6(2), 87-100.

[4] Dweck, C. S., \& Leggett, E. L. (1988). A social cognitive approach to motivation and personality. Psychological Review, 95(2), 256273.

[5] Piaget, J. (1964). Part I: Cognitive development in children: Piaget. Development and learning. Journal of Research in Science Teaching, 2(3), 176-186. https://doi.org/10.1002/tea.3660020306

[6] Shaw, A. (2009). Education in the 21st Century. Ethos, 17(1), 11-17. https://doi.org/10.1080/15374418-009532979

[7] Fisher, A. (2001). Critical Thinking. An Introduction. Library, 44(13), 17. https://doi.org/10.2307/2019787

[8] Dale, E. (1946). The “Cone of Experience." In Audio-visual methods in teaching (pp. 37-51).

[9] Cronbach, L. J. (1988). Five perspectives on the validity argument. In Test Validity (pp. 3-17). https://doi.org/10.1017/CBO9781107415324.004

[10] Brown, T. (2008). Design thinking. Harvard Business Review, 86(6).

[11] Gavan, A. (2012). Visual, Auditory and Kinesthetic (VAK) learning style model. James Cook University. Retrieved from http://www.jcu.edu.au/wiledpack/ modules/fs1/JCU_090460.html

[12] Meier, Dave. (2002). The Accelerated Learning Handbook: Panduan kreatif dan efektif merancang program pendidikan dan pelatihan. Penerjemah : Rahmani Astuti. Bandung : Kaifa.

[13] King, A. J. (2009). Visual influences on auditory spatial learning Philosophical Transactions of the Royal Society of London. Series B, Biological Sciences, 364(1515), 331-339. Retrieved from http://rstb.royalsocietypublishing.org/cgi/doi/10.1098/rstb.2008.0230 Inhttp://rstb.royalsocietypublishing.org/content/364/1515/331.short

[14] Rose, D. (2014). Accelerated learning. Education Training. Retrieved from http://www.ncsl.org/research/ education/accelerated-learningoptions.aspx

[15] Capps, D. K., \& Crawford, B. A. (2013). Inquiry-Based Instruction and Teaching About Nature of Science: Are They Happening? Journal of Science Teacher Education, 24(3), 497-526.

[16] Dhingra, K. (2003). Thinking about television science: How students understand the nature of science from different program genres. Journal of Research in Science Teaching, 40(2), 234-256.

[17] Conway, M. A. (2005, October). Memory and the self. Journal of Memory and Language.

[18] Dweck, C. S., \& Leggett, E. L. (1988). A social cognitive approach to motivation and personality. Psychological Review, 95(2), 256273.

[19] Jensen. (1969). "How much can we boost IQ and scholastic achievement": Addendum. Harvard Educational Review, 39(1), 1123. https://doi.org/10.1037/h0037827

[20] Ennis, R. H. (1993). Critical thinking assessment. Theory Into Practice.

[21] Kemmis, S. (2009). Action research as a practice-based practice. Educational Action Research, 17(3), 463-474.

[22] Cronbach, L. J. (1975). The two disciplines of scientific psychology. American Psychologist, 30(2), 116-127. https://doi.org/10.1037/h0076829

[23] Abidin, Yunus. (2014). Desain Sistem Pembelajaran Dalam Konteks Kurikulum 2013. Bandung : PT Refika Aditama.

[24] Blackwood, B. (2007). Snatch Skill Transfer Exercises. Strength and Conditioning Journal, 29(6), 62-66. Retrieved from http://pibserver.us.es/gtb/usuario _acceso.php?centro= $\$$ USEG\&centro $=\$ U S E G \& d=1$

[25] Gardner, H. (1985). Frames of Mind: The Theory of Multiple Intelligences. The Theory of Multiple Intelligences. https://doi.org/10.2307/3324261

[26] Cronbach, L. J. (1975). The two disciplines of scientific psychology. American $\quad$ Psychologist, 30(2), 116-127. https://doi.org/10.1037/h0076829 